\title{
TRANSFORMATION OF WAR - USE OF CONVENTIONAL MILITARY FORCES AGAINST STATE ACTORS
}

\section{Short content}

Immediately after the initial military success of the US military in 2001 and the overthrow of the Taliban regime in Afghanistan, insurgent mujahedeen groups quickly began to form. Mixed insurgent groups formed by the Taliban, Hezbollah and Islamists, the Haganah network, foreign mercenaries, local tribes, and criminal organizations have been pushing hard to overthrow the Afghan government. The efforts of the United States and its coalition partners in dealing with the mujahedeen forces have provided an excellent opportunity to assess what works and what does not work in terms of fighting an asymmetric enemy by conventional means in an unconventional combat environment.

The questions on which this research is based are: Why has modern sophisticated military technology and numerous conventional military superiorities failed to deal with the $4 G B$ insurgent groups and failed to meet the expected results in countering threats to stability in Afghanistan? In this scientific paper, we will give an answer to this research question and at the same time, we will try to prove the reasons that led to the change of the essence and the conduct of the war in the XXI century.

Keywords: WAR, REBELLION, TERRORISM, SECURITY, ASYMMETRIC THREATS

\section{Introduction}

Soviet counter-insurgency tactics and the Afghan mujahedeen warfare in the 1980s marked an important period in the era of insurgency and counterinsurgency operations. This conflict can be considered as a transitional phase between the traditional riots in the twentieth century and the modern riots that are categorized as 4GB. Mujahideen warfare and Soviet anti-insurgency tactics include elements of older models of warfare that blend with elements of new forms.

The Afghan insurgent mujahedeen movement has been a movement as well as many traditional insurgencies throughout history, with the exception of external support and funding and an influx of Muslim fighters from around the world. Most operations were carried out by small mujahideen units against the Soviet occupiers, and Soviet military supremacy was not a decisive factor 
in the struggle between the rebels and Soviet forces. Some mujahedeen units functioned as real formation military structures.

The war in Afghanistan was an asymmetric conflict, as the Soviet Union waged a limited war while the mujahideen waged total war. Moscow has deliberately limited the size of its military forces and their engagement. On the other hand, the resistance of the mujahideen was a total war for the survival and future of their country. The Soviet army did not lose the war in Afghanistan, it simply failed to win and achieve the desired goals. In addition, the army returning from Afghanistan was physically and mentally defeated. The Mujahideen, on the other hand, were not victorious but remained undefeated and disobedient. The guerrillas knew they had not won a convincing victory, but were aware that they had undermined the will of the invaders to wage war in the future. In essence, the mujahideen fighters proved Kissinger's maxim: "Guerrillas win if they do not lose and the conventional army loses if it does not win." The mujahedeen-guerrilla resistance in Afghanistan has effectively countered the Soviet strategy of destruction by waging a protracted war through a process of gradually reducing the number of Soviet troops, reducing their military strength and efficiency, and keeping them under constant stress.

\section{Global Jihad and Revolution in the Military Environment}

During the 1990s, the US military was in the throes of a military-technological revolution. Driven by the success of Operation Desert Storm, which demonstrated the development of modern military technology with global positioning systems and precision weapons, the vision for future wars was presented. At the same time, another revolution took place that incorporated elements from the revolutionary era of France. This revolution was created by the al-Qaeda terrorist network, which scored through the ever-growing religious and social movement, which focused on fundamentalist Islamist beliefs. This organization is already showing the capacity to adapt to the sophisticated technology and organizational structure of its enemies. By mobilizing radical Islamic elements, it will slowly transform into an organization that has the capacity to carry out an attack on a global level and achieve strategic results, by carrying out small terrorist acts, on a tactical level.

The radical Islamist movements that can be found in the Middle East have different roots and reasons for their formation, dating back to the beginnings of Muslim history. At certain times in this Muslim history, radical Islamists have resorted to methods of violence and terror to achieve their political or theological goals within their means and capacities. However, modern extremist movements have become a powerful global force based in the Middle East that benefits from several hotbeds of Arab discontent.

From 1990 to 2001, al-Qaeda leaders Osama bin Laden and Zawahiri would transform al-Qaeda into a global threat to US national security. The culmination came with the 9/11 attacks. In that period, al-Qaeda will become a 
coalition of factions of radical Islamist jihadist groups operating throughout the Muslim world. They will set up their own cells and collaborators in hundreds of countries. Osama bin Laden, through a combination of new information technologies and his well-known universal motivation for Islamic militant extremists - fatwas, will create a powerful terrorist organization capable of carrying out attacks around the world. This massive cyber mobilization is in a phase of an irreversible process that will have a huge impact on the conduct of future wars. By using this network, which has cells and collaborators across all continents, al-Qaeda is able to maintain its structure and achieve its goals across a wide range of different cultures (Scheuer, 2005).

In 1996, Osama bin Laden cited the incident in Somalia and proved the obvious political weakness of the United States - public opinion, when a slain US soldier was dragged through the streets of Mogadishu, followed by the withdrawal of US troops from Somalia and Rwanda (Bethune, 2007). Terrorist attacks organized by al-Qaeda from a military point of view are unconventional. From 1998 to the present, al-Qaeda has carried out numerous suicide bombings by planes, cars, trucks, churches, synagogues, consulates, schools, and military bases and ships. Their purpose varied from light civilian targets to high-security military installations (Schweitzer, 2010).

Globalization and the latest information technology will enable isolated al-Qaeda cells or individuals to easily connect with each other and mobilize attack resources without any support from training camps, leaders, and the terrorist organization's central base. What makes al-Qaeda different from conventional military organizations is its efforts to achieve strategic effects, with low-budget tactical operations. Al Qaeda's goal is to destroy cultural values and societies globally, through the use of subversion and armed conflict, with the ultimate goal of establishing a new world order. On the other hand, al-Qaeda is waging a global insurgency to achieve its strategic goals by operating small independent cells that use relatively sophisticated weapons systems in their operations. This is very clear from the $9 / 11$ terrorist attacks, in which a small terrorist group of about 20 operatives killed more than 3,000 civilians in less than four hours.

We can conclude that al-Qaeda's military revolution, despite the persistence of NATO and the United States in suppressing it, continues to develop and increase its capacity to carry out terrorist attacks. This rise has not been achieved by using high-tech military systems but by less sophisticated methods (for example, suicide bombers on commercial aircraft). By carrying out this military revolution of terrorist organizations such as $\mathrm{Al}$ Qaeda, the competence and usefulness of the armies for tactical warfare is being undermined. The example of the United States shows that despite the enormous efforts of this country to physically destroy the al-Qaeda network by using tactical force, it continues to remain operational and capable of achieving strategic goals, by carrying out terrorist attacks on strictly selected targets around the world. 


\section{Fourth Generation Wars vs Fourth Generation Asymmetric Enemies}

On October 7, 2001, the United States declared war on terrorism and labeled it a universal enemy against the entire civilized world. The main goal of the US military intervention was to destroy al-Qaeda and its bases in Afghanistan, protected by the Taliban regime. Since then, the US military campaign has undergone a change of strategy on several occasions, from an enemy-focused counter-terrorism approach to a population-focused counterinsurgency approach.

Al-Qaeda leaders had several assumptions about the reactions to the 9/11 attacks. They assumed that the Bush administration, like some of its predecessors, would conduct lengthy investigations and be slow to take military action against al-Qaeda and Afghanistan. In any case, al-Qaeda had no idea how much it would increase the anger of the United States and its allies by killing 3,000 innocent people in 90 countries around the world. Washington has asked the Taliban government to hand over al-Qaeda leader Osama bin Laden. But the Taliban leader, Mullah Omar, rejected their demands, as he did in 1998, even though there were about 12,000 al-Qaeda fighters in the country (Lennox, 2005). George W. Bush “to use all necessary and appropriate force against the peoples, organizations or persons who concealed, assisted, planned, authorized and carried out the 9/11 terrorist attacks in order to prevent any international terrorist acts in the future."

On October 7, 2001, the United States launched airstrikes on Afghanistan. Towards the end of the month, CIA paramilitary teams and US Army special operations teams were deployed and began cooperating with the Northern Alliance and friendly Pashtun tribes in the south. At the time, Pakistan was supporting mujahedeen groups and the Taliban. But after the 9/11 attacks, Pakistani authorities were offered an alternative opportunity to support the United States or be at war with them. Pakistan has easily provided the United States with the logistical support and facilities needed to wage war against Afghanistan. During the 1980s, through Pakistani smuggling channels, the United States, in cooperation with Pakistan's intelligence service, provided weapons to Afghanistan's most extremist fundamentalist mujahedeen groups. After the Soviet withdrawal in 1989, US aid ceased, but Pakistan's intelligence service continued to support extremist religious factions and the Taliban in Afghanistan. After 9/11, US and Pakistani intelligence services entered into an alliance. This time, their goal was to overthrow the regime in Kabul, previously installed by the Pakistani intelligence service. CIA agents suspected the sincere intentions of the Pakistani intelligence service to cooperate (Dobbins, 2008).

In the first phase, despite remarks by the George W. Bush administration about "transforming the war" and waging a long asymmetric $4 \mathrm{G}$ war, the ground forces of the Afghan United Front (Tajik, Khazar, Uzbek, and anti-Taliban Pashtun tribes), US special forces and Britain, with massive support from the US Air Force, waged a classic conventional war. At this stage, an effective and 
comprehensive counterterrorism strategy to combat al Qaeda and the Taliban regime was built on a combination of military action, law enforcement, a freeze on funding, and the renewal of international cooperation agreements. The use of tactical aircraft, armed with the latest generation of weapons, has given the United States a consistent and immediate advantage on the battlefield. The resistance was broken very quickly, and the Taliban and al-Qaeda members fled to the eastern mountainous regions of Afghanistan. Operation Anaconda, carried out in March 2002, was a battle that was fraught with tactical and command problems, but ultimately succeeded in defeating the hardline Taliban and al-Qaeda mujahideen in the Shari Kot Valley (Lambeth, 2005). In general, the conventional operations carried out by the United States were successful, but not crucial. The United States has neither destroyed its enemy nor its willingness to resist. Taliban insurgents were defeated on the ground, the regime ousted, and Osama bin Laden and Mullah Omar fled with large numbers of al-Qaeda leaders (about 1,000 mujahideen) to safe havens in Pakistan and other neighboring countries. For al-Qaeda and other radical groups, the United States and its allies have become occupiers of Islamic countries.

The American way of fighting in Afghanistan, in the period from the beginning of the attacks from October 2001 to April 2002, can be described in four stages. The initial first phase of the war was very short and used only the air force, which did not achieve significant success. In the second phase, special operations forces were deployed to assist their Afghan allies in the Northern Alliance. The US Special Operations Forces, in co-operation with Northern Alliance units, have been able to drive the Taliban and al-Qaeda from their conventionally occupied defensive positions in the mountains. In the third phase, the operation was performed in the mountainous area of Tora Bora. US special forces and unprepared allied Afghan forces have been unable to simultaneously fight the Taliban and al-Qaeda and block the porous border with Pakistan. The fourth phase is Operation Anaconda, in which the United States uses conventional military forces, aided by local Afghan leaders, to oust al-Qaeda from its last stronghold, the Shah-i-Kot Valley. But al Qaeda and the Taliban were once again able to escape across the border into Pakistan. If we look at this part of the war realistically, it is obvious that al-Qaeda fighters in the first two phases do not apply 4GB elements. They were established in conventional defensive positions. Only after being expelled from the mountains by a powerful conventional military force could they fight in the most effective way - from caves, where they were deployed in small groups to fight against conventional US forces. The fourth generation of opponents does not demand the defeat of enemy forces. They choose to wage war in another way. In Nicaragua, Chechnya, Afghanistan, and Palestine, insurgents have never defeated enemy forces. They focus on winning wars, not battles (McIvor, 2007). 


\section{Al Qaeda in Afghanistan - a new generation of asymmetric threats}

Twenty years after 9/11, there is still a lack of consensus on the current state of al-Qaeda. Washington officials say al Qaeda is at an impasse and that the United States is within reach of a strategic victory over al Qaeda. But while some argue that al Qaeda is weaker today than it was in 2001, others warn that it is still a serious threat today. The assessment of whether al-Qaeda remains a serious global threat or perhaps even more dangerous today than it was before 9/11 is based on several facts. Al Qaeda's periphery remains very strong despite its weakening center. The United States won many battles on the battlefield but lost the ideological battle. Al Qaeda allies are increasingly embracing its ideology of global struggle. The boundaries between Islamic radical jihadist organizations no longer exist. Al Qaeda continues to recruit and radicalize new domestic terrorists around the world. It continues its low-level terrorist campaign, eventually weakening the United States economically and withdrawing from Afghanistan following the example of the Soviet era. The US withdrawal from Afghanistan and Iraq also paves the way for a resurgence of al-Qaeda.

From another perspective, in recent years it has become clear that al-Qaeda has reduced its operational capabilities. Their protector - the Taliban in Afghanistan - was defeated. Easily accessible terrorist camps, a training ground for world jihadists, were dispersed. Al Qaeda attacks in Indonesia, Tunisia, Egypt, Morocco, Saudi Arabia, Jordan, and Turkey between 2002 and 2006 prompted governments to try to destroy local terrorist networks. The perpetrators of the 9/11 attacks have been killed or captured. The leader and founder of Al Qaeda are dead. The remaining leadership is decimated. Their brutal methods of ruthlessly killing Muslims reduce their chances of recruiting new members. Cooperation between security services and law enforcement between states has created a new hostile environment for terrorist organizations. Al Qaeda has not been able to carry out significant terrorist operations since 2005, but it is still capable of planning credible worrying attacks.

For the CIA, al-Qaeda is a terrorist organization with the greatest nuclear ambitions (Hayden, 2008). In the 1990s, al-Qaeda operatives tried unsuccessfully to obtain nuclear material. In 1998, bin Laden appointed his deputy, Ayman al-Zawahiri, to be in charge of developing nuclear weapons, mediating talks with renegade Pakistani scientists shortly before the 9/11 attacks. All the evidence and documents seized from al-Qaeda and the Taliban in Afghanistan point to the fact that jihadists have shown a continuing interest in nuclear weapons, but also a lack of knowledge on how to make weapons (Albright, 2009).

The lack of experts and materials to obtain WMD does not preclude the ability of the new al-Qaeda leadership to acquire nuclear weapons. Online calls for jihad further fuel the followers' fantasies, while alerting the intelligence services to a possible nuclear attack. Al Qaeda is the first terrorist organization to invoke virtual nuclear power without any physical evidence of it. A much more likely threat from acquiring a nuclear detonation device is to create a "dirty 
bomb" that could carry out a biological attack. This threat is more likely because the production and availability of materials for making this bomb are much easier than that for nuclear. Castor (a poison made from castor beans) and botulinum toxin are the tools mentioned in several terrorist plots uncovered after 9/11. Al-Qaeda has also carried out experiments with the anthrax bacterium in laboratories in Afghanistan (Aytaç, 2009).

\section{Structure of the new generation of hybrid wars - 5GB}

The strategic architecture used by al-Qaeda in the "war on terror" is nothing new. It is basically a modern application of known and new concepts of warfare.

One of the basic approaches to understanding this type of war, and which we could apply, is to bring the so-called "war on terror" in correlation with the evolution of warfare in modern conditions. In fact, this recognizable approach explains the development of modern warfare in the 21st century, depending on: political, economic, social, and technological changes in society. Regarding the derived classifications of wars, we can conclude that each of the generations of wars represents a qualitative dialectical change in the methods of waging wars. The litmus test of the emergence of a new generation of wars is the defeat of large armies, using the methods of the previous generation of warfare.

Currently, there is no generally accepted definition of fifth-generation wars. However, given the level of change that is increasingly becoming a reality, it is necessary to talk about a new fifth generation of warfare. It took hundreds of years for the Musketeer rifle and cannon to develop during the first generation of war, for the emergence of the second generation of warfare to mark its $100^{\text {th }}$ anniversary between the battles of Waterloo and Verdun. The third generation with the advent of "blitzkrieg" (maneuver) warfare reached its full expression in less than 25 years. The fourth generation of warfare has been widely used since its inception in China eighty years ago, at a time when the third generation of warfare is widely used throughout Europe.

If we talk about the fifth generation of wars, its definition would be "a war in which all the means at its disposal are used, namely the means of the armed forces and unarmed opposition, means that include military power and means that are not related to the manifestation of military power, assets that include losses and assets that are not related to losses, are in order to force the enemy to act according to the set interests. This includes the emergence of superpowered individuals and groups to whom modern knowledge, technology, and tools are available to perform asymmetric attacks and to pursue their individual and group interests. Its first manifestation is related to the attack with the chemical agent "Anthrax" in the USA in 2001 and the attack with the poisonous gas ricin in 2004. Both types of attacks required specialized knowledge, including the US federal government's attack on its services and facilities, which resulted in disruption of government work and widespread public fear. To date, there is 
no individual or group that has claimed responsibility for any of these attacks, and none of these attacks have been fully resolved.

Computer hackers today are able to hack into the work of government agencies or corporations globally, with cyber attacks, with their own computer programs blocking their work, which on the other hand can only be a precursor to the pronounced influence of superpowered individuals and groups. By doing so, they are actually demonstrating the ability to take on and run campaigns on their own, which is in fact a confirmation of the foundation of the new fifth-generation warfare.

The potential power of fifth-generation warfare was also demonstrated in the 2004 Madrid bombings. A series of massive bombings of transport infrastructure led by networked terrorist groups in a single day, in the wake of the national elections, resulting in a state of emergency in the Spanish government that affected the immediate withdrawal of Spanish troops that were engaged in the military campaign against insurgents in Iraq.

The Madrid bombings are significant because the terrorists behind them were the main drug dealers and part of the drug network that stretched from Morocco through Spain and Belgium to the Netherlands. While initial estimates of the cost of the bombs used ranged from around 50,000, the total earnings found in drugs and cash associated with the attacks reached millions of pounds. It was learned that the group that carried out the terrorist attacks is part of an international criminal organization, which had behind it the participation in regime changes in several sovereign European countries. This engagement demonstrates the dialectical advantage of the fifth generation of warfare over the already known methods of warfare of the third and fourth generations of warfare.

\section{Countless wars}

The beginnings of erosion of the base for the triple construction of war began first with the emergence of democracy and later with nationalism. Technological development has further accelerated the trend of non-triple wars. The end of the Cold War and the growing number of unconventional armed conflicts, in academic and military circles, provoked a great deal of discussion about changing the character and nature of war. These developments, also encouraged by the work of scientists in their attempts to grasp the complexity of the phenomenon of globalization, have led to a rethinking of the central assumption of war that dominated the Cold War - strategic thinking about war. Thus, according to Clausewitz, the way of thinking about the war became the target of fierce criticism.

Clausewitz defined war as "an act of violence intended to force the adversary to do our will." According to him, the war was conceived as a national, instrumental, controlled, and rational political act. For him, war is waged only for a clear purpose, with rational costs and benefits from the use of force. In 
such wars, victory belongs to those who best practice the martial arts. Clausewitz also distinguished between the nature and character of war. According to him, while the nature of war is unchanged, its character changes depending on the time in which it occurs. This means that even when the face of war changes as a result of modern technology, political environment, historical context, etc., its nature of organized violence remains constant. These tendencies correspond to three institutions: the people, the military, and the state which are known as the miraculous trinity. Clausewitz also emphasizes the importance of balance between the components of the trinity.

Martin van Creveld, in his book Transformation of War, gives a critical overview of the $4 \mathrm{GWs}$, in terms of the western view of warfare and their inability to understand the dynamics of warfare in future conflicts. The Western model of war (state against state) led by powerful armored forces is obsolete due to the constant presence of the nuclear threat. Furthermore, the influence of governments on the monopoly of war is constantly declining. Additionally, in many parts of the world, even in the $19^{\text {th }}$ and $20^{\text {th }}$ centuries, states were established through colonization and decolonization. In some parts of the world, the functioning of states has never fully developed. Even when states are established, other organizations come to the fore, and war, people, or armies are not involved in waging war, but groups we today call terrorists, tribes, religious groups, commercial groups, criminal groups, insurgents, or, in short, non-state actors.

These non-state actors wage wars in a very different way from nation-states. War is a cultural phenomenon and for many peoples, war can have different purposes (symbolic, ritual, or existential) that are followed by different rules, not so close, and limited by politics. These fundamental differences produce very different strategic dynamics. With this Western model of warfare through which the nation-state loses ground, this intransigent way marked the changes in the attitude towards the future 5GB, in terms of who will be led, what they will be fought for, and what kind of wars will be fought and why people will participate in them.

In recent decades, major conventional wars have been few, while wars against or between non-state organizations have spread and continue to spread. Among those that have spread but been brought to an end (sometimes more, sometimes less) are those in Algeria, Angola, East Timor, Egypt, Lebanon, Mozambique, Northern Ireland, Rwanda, Somalia, and most regions of the former Yugoslavia. Those that have expanded and not been brought under control are those in Afghanistan, Chechnya, Colombia, Congo, Kashmir, Liberia, Israel, the Philippines, Sierra Leone, Sri Lanka, Sudan. Some of them can be described as terrorism, others as guerrilla warfare, some as open battles between opposing armies, and some as pure genocide. The core of these conflicts lies in the fact that, unlike conventional wars, they were not triple. 


\section{Conclusion}

The global jihad is formed through a complex network of dependencies and patronages, oriented towards the overthrow of the world order and its replacement with a Pan-Islamic caliphate. Defined in this way, global jihad is a rebel movement that seeks to change the status quo through violence and subversion, while terrorism is one of its key tactics and hence an integral part or subset of the insurgency. But while traditional insurgents have sought to overthrow the government or social structures in a country or region, this insurgency seeks to transform the entire Islamic world and redefine its relationship with the rest of the world. The instruments of globalization are the Internet, globalized communications, international finance, freedom of movement - allowing tactics, intelligence, personnel, and finance to be exchanged between jihadist groups.

The systemic enemies, not only al-Qaeda terrorists and their supporters, but also ethno-nationalist fighters in places like Chechnya, Sri Lanka, criminal groups in Colombia and Russia, street gangs and anarchists from Los Angeles to London, gained strength from what they completed through the five levels of theory and practice:

$\Rightarrow$ organizational level - their systematically organized structure;

$\Rightarrow$ scientific level - team strategies and methods as a whole;

$\Rightarrow$ technological level - their information system;

$\Rightarrow$ social level - interpersonal relationships that provide loyalty and trust;

$\Rightarrow$ narrative level - the story they tell themselves and others.

The power of this non-state fifth generation of asymmetric enemies depends on its coordinated action at all levels. If the network is composed of well-defined tactics with a winning story, through strong social and personal contacts supported by the latest technological communication systems, it will be invincible. A classic example is the battle won by al-Qaeda against the United States on September 11. A series of coordinated 9/11 attacks has proven to the world that globalization has increased the ability of terrorist organizations and other non-state actors to project power into the global environment.

In the same way, global insurgency uses events from one region to another. Their aim is to spread the realm of Islam (Dar al Islam) over the whole of human society. This Islamist strategy aims to provoke a clash between Islam and the West, to generate an Islamist front, and thus to mobilize Muslims, whom Islamists see as oppressed victims. Hence, jihad is a global uprising. Al Qaeda and similar groups are constantly regenerating daily from local insurgent movements around the world, integrating them into broader ideologies, and linking different/incompatible conflicts through globalized communications, finance, and technology. Hence, the main feature of the Islamists is not their use of terrorism, a tactic they share with dozens of movements around the world, but because they are a global insurgency against the world order, which like all other insurgent movements uses terrorism, along with other tactics ranging from subversion and propaganda to open-armed struggle. 
Much of the task of defending societies from non-trivial wars will fall to private security companies, with a corresponding reduction in services, size, and technological complexity, and cost to the military. Thus, the armies will be reduced in size and set aside to be replaced by the police as security forces on the one hand, and armed robber gangs on the other. Given the emotions involved in dealing with this type of conflict, the party with more rational interests is likely to lose. The Western model of the nation-state as a dominant form of political organization and a related form of warfare with conventional methods of dealing with the $5 \mathrm{GV}$ and "innumerable" enemies will slowly go down in history.

We can conclude that the greatest security challenges today, and in the future, will come from failed states and disturbed regional security, with repercussions around the world, and the rise of terrorism that flourishes in areas where there is a lack of political control. The essence of today's war is asymmetry. The "enemy" adapts to unconventional strategies such as riots and terrorist attacks. Today's "enemy" of the fifth generation, in modern conflicts, is network-based, flexible, and transnational in scope, enabled by modern technology.

\section{Bibliography}

Albright D. (2009). Al Qaeda's Nuclear Program: Through the Window of Seized, November 19.

Aytaç O. (2009). Defence Against Weapons of Mass Destruction Terrorism, IOS Press, Amsterdam.

Benjamin S. Lambeth, (2005). Air power against terror: America's conduct of Operation Enduring Freedom", Rand Corporation, Santa Monica.

Bethune B. (2007). The ghost of a man I never knew, Macleans.ca.

Dobbins J. (2008). After the Taliban: Nation-Building in Afghanistan, Potomac Books, Washington.

Hayden M. (2008). CIA Director, Director's Remarks, at the Los Angeles World Affairs Council

Lennox G. (2005). Forged by war: Australians in combat and back home, Melbourne Univ. Publishing, Victoria.

McIvor A.D. (2007). Rethinking the Principles of War, Naval Institute Press, Annapolis.

Scheuer M. (2005). Can al-Qaeda Endure Beyond bin Laden? Terrorism Focus, Vol. 2.

Schweitzer Y. (2010). Al-Qaeda and Suicide Terrorism: Vision and Reality, Military and Strategic Affairs Volume 2, No. 2.

Yarger H.R. (2010). Short of general war-perspectives on the use of military power in the 21st century, Strategic Studies Institute, Carlisle. 
